\title{
The Poet Glorifies his Poetry: AL-Mutanabbi and Shakespeare as a Model
}

\author{
Rashid al-Essa \\ Department of Arabic Language and Literature, Al-Balqa Applied University \\ Princess Alia University College, Jordan \\ Sura M. Khrais \\ Department of English Language and Literature, Al-Balqa Applied University \\ Princess Alia University College, Jordan \\ E-mail: surakhrais@yahoo.com
}

Received: 15-02- 2015

Published: 01-09- 2015
Accepted: 22-04- 2015

doi:10.7575/aiac.ijalel.v.4n.5p.206
Advance Access Published: May 2015

URL: http://dx.doi.org/10.7575/aiac.ijalel.v.4n.5p.206

\begin{abstract}
This paper aims at studying the aspects of and the reasons behind the poet glorifying his poetry and, consequently, himself. The two examples chosen here are Al-Muttanabi, the famous Abbasid poet and Shakespeare, the Elizabethan poet. The researchers discuss the common features that distinguish the poetry of both poets especially in relation to the theme of glorification of poetry. This comparative study has chosen examples from Al-Mutanabbi's poetry (the Diwan; the collection of his poems) and Shakespeare's sonnets (18-126). The researchers have found out that the two poets glorify their poetry while praising an outstanding powerful character in order to make profit or gain a social status or a governmental position. Ironically speaking, they end up hinting at the fact that their poetic lines are immortal and only through their panegyric poetry the concerned patron is immortalized.
\end{abstract}

Keywords: Glorification of poetry, al-Mutanabbi's panegyric poetry and Shakespeare's sonnets, poetic immortality, verbal prowess, the poets' patrons

\section{Introduction}

The comparative nature of this study adds much to its originality. The paper's substantive focus on Al-Muttanabi, the Abbasid poet and Shakespeare, the Elizabethan poet in relation to the theme of glorification of poetry is the core of this study. It is important to emphasize that this paper follows the modern American school of comparative studies which defines this approach as a cross-cultural one that pays no heed to national borders and which has surpassed the earlier nation-based approach in favor of a transnational study (Remak, 1964). Thus my paper discusses places of meeting among the poetry of two poets who wrote in two different languages reflecting their two different cultures. It is the purpose of this paper to address a gap in comparative research which has been so far confined to studies comparing alMutanabbi to other Arabic classical writers (Abbas, 1973; Larkin, 1986; al-Haydar, 2009; Askari, 2010; Shareem, 2013) and Shakespeare to other Classical and Western writers (Morgan, 2009; Driver, 2009; Nda, 2011; Iseni, 2014), but rarely combined both poets. This paper investigates selected lines of al-Mutanabbi's Diwan (Collection of his poetry) and of Shakespeare's sonnets seeking to reveal how the two great poets glorify their lines while praising their patrons.

\subsection{Importance of the Study}

Though many studies have been written about the two poets, no one comparative study focuses on the common aspects of glorification of poetry and the reasons behind it. For instance, Mohammad Taqi John studies intertexuality found between al-Mutanabbi and different writers such as the Spanish novelist Miguel de Cervantes, Nietzsche, classical epics, Western folklore and fairy tales. His discussion of intertexuality between al-Mutannabi and Shakespeare is limited to the latter's play The Merchant of Venice ( John, 2011). The closest study to the theme of this paper is by Shiraz Azzab who assumes that Shakespeare "has always suffered from Arabomania" or what she precisely defines as "al-Mutanabbiomania"( abstract, 2013)! Azzab focuses on Shakespeare the poet and the playwright. She believes that he owes much in his poetic language to the eastern bard (p. 10). However, a great section of her research studies four characters of Shakespear's drama and how much he was influenced by the Eastern culture and al-Mutanabbi in depicting them. Nevertheless, Azzab'sstudy does not give a specific attention to the theme of glorification of poetry.

\subsection{Scope of the Study}

Both poets mocked time and praised the immortality of their poetic lines. Nevertheless, the distinguished style and values celebrated in their poetry have earned them a special position in the world of literature. However, Al-Mutanabbi and Shakespeare are controversial poets much of whose personal lives remained a mystery. By studying different 
examples from al-Mutannabi's panegyric poetry and Shakespeare's sonnets, the researchers tend to explore the possible justification(s) behind this exaggerated tone and proud spirit found in the poetry of both. However, it becomes clear that such a wish to elevate poetry reflects a human wish and is a universal feature of different cultures and literature.

\section{The Distinctive Characteristics of Al-Mutanabbi's poetry}

Abu al- Tayyib al-Mutanabbi; AhmadIbn Al-Hussein Al-Koufi (A. H. 915-965), is a major figure in classical Arabic poetry. He is well known for his sharp wit and intelligence. His poetry is bold, hyperbolic and hypnotic. His great talent brought him very close to many leaders of his time. He praised many kings and leaders in return for many gifts. His panegyric poems took him from court to court, from fame to greater fame, and influenced wordsmiths for centuries after. He has been called the "Seal of the poets," and "his words continue to echo, enlighten, annoy and delight more than a thousand years after his death" (Qualey, 2013, p. 1).In praising him the French orientalist Blachere says that AlKoufa, the birth place of the poet, has produced many strange characters but none could compete with Abu-Attayeb alMutanabbi. This city that caused much worry to the East because of the boldness of its citizens has provided the world with a man who incarnates the philosophy of equality in Islam. He adds that the reason behind the great fame alMutanabbi has achieved up to the modern time is that he represents Arabic genius as opposed to non-Arabic genius. (Blachere, 1985, p. 2).

Al-Mutannabi had a great pride in himself and had shown that through his poetry:

Who is the great man I should avoid/ what status I should aspire

Everything God has created/ and everything he hasn't

Is mean compared to my will/ as a hair in my head. (p. 40).

Here, the persona asserts that he is greater than greatness itself. Through two rhetorical questions, he boasts that there is no man of importance he should avoid, and no great status would satisfy his ambitions. He boasts saying that all God's creation and what God has not created yet is mean compared to the greatness of his will. In another outstanding line, AlMutanabbi describes his greatness through a bombastic image that has the features of a caricature and a surrealist scene, thus dramatizing himself as a mythical statue: "My esteemed self, if I am standing upright/ the whole creation is under my feet" (p. 164).

The persona suggests here that if all creation are under his feet and he is standing above them, he wouldn't even reach the aspirations of his will. Al-Mutanabbi's excessive pride and feelings of greatness have motivated him to belittle others. The previous lines would have been insulting for prince Sayf al-Dawla al-Hamadani; al-Mutanabbi's patron and to whom the poet has dedicated much of his panegyric poetry.

Al-Mutanabbi's praise of prince Sayf al-Dawla Al-Hamdani; the poet-prince of northern Syria, contributed much to the earlier's fame in the tenth century. "Sayf al-Dawla Al-Hamdani was the most celebrated prince by poets. No kings- who followed the Muslim Caliphs- had ever the same number of great poets and distinguished literary figures as AlHamadani had at his doorstep" (al-Hashem, p. 12). In 948, al-Mutanabbi attached himself to Sayf al-Dawla. During his nine years stay at Sayf al-Dawla's court, al-Mutanabbi versified his greatest and most famous poems. He wrote in praise of his patron panegyrics that rank as masterpieces of Arabic poetry. Most researchers agree that Al-Mutanabbi exaggerated in praising himself hoping to fulfill his great political ambitions to become Wali or a statesman. Unfortunately, al-Mutanabbi lost Sayf al-Dawla's favor because of this ambition. In addition, Abu al-Misk Kafur AlAkhsheidi in Egypt never granted al Mutanabbi his wish. Thus, the latter's outcry is deeply felt: "I want Time to aspire to my will/ a wish Time cannot aspire for himself." (p. 471). While praising the prince, Al-Mutanabbi continues to glorify himself, his poetry and his mastering of art of chivalry. Sometimes glorifying himself would surpass praising the prince. Openly swollen with pride of his supremacy as a poet, al-Mutanabbi often praises himself in such bombastic lines. His pride often enters the realm of arrogance which has become, ironically speaking, the foundation of much of his poetry.

In his famous poem, "My Heart is a Flame," Al-mutanabbi praises himself while praising al-Hamdani and criticizing him indirectly.

My deep poetic art the blind have eyes to see

My verses ring in ears as deaf can be,

They wander far abroad while I enjoy my sweet repose,

But men collect them watchfully with toil and care. (p. 332-333)

Al-Mutanabbi is extremely proud of his writing which the blind can see and the deaf can hear. While he is content with complete verses and able to sleep, other poets strain for simple rhymes. The proud poet also says:

Swift steeds, dreary nights, and the desert, all know me full well/As do the sword, the spear, the paper and the pen. (p.333)

He is known to the knights, the desert and the night. He is a brave warrior and, most important, a great poet. Thus, he is well-known to the writing paper and to the reed. Boldly, he declares: "Now, this court will learn/ that I am the greatest in wit and courage." Al-Mutanabbi strongly believed in his majestic grandeur to the point that, it was in his youth, he claimed to be a prophet, hence the name al-Mutanabbi ("the Would-be Prophet"). According to some interpretations, he likened himself to Prophet Saleh in some of his verses. However, this point remains controversial among many Arab 
critics and western orientalists. For not being well appreciated by al-Hamadani or al-Akhsheidi, Al-Mutanabbi continues to declare strong feelings of being an outsider:

Staying here in the land of palm trees (Baghdad)/ as a Christian among the Jews,

Here, a nation cursed by God/ I am an outsider as prophet Saleh in Thamud (p.20)

Another reason behind this pride is the fact that Al-Mutanabbi wished to compensate for his family's poverty . His father was a water carrier who also claimed noble and ancient Yemenite descent from Kindah, a well-known Arabian tribe (Vuong \& Mégarbané, 2012, p. 7). Nevertheless, Al-Mutannabi was extremely clever, proud and rebellious. "No Arab poet has ever aroused much argument among critics as Al-Mutanabbi; his life and poetry have motivated great criticism in Arabic Literature and the works of orientalists more than any other Arab poet" (Blachere, p. 373). Blachere has provided us with the names of more than thirty European orientalist who have studied the poetry of Al-Mutanabbi. Some of them admired it strongly such as Hammer while others detested his arrogance such as Reisk. For example, different orientalists emphasize al- Mutanabbi's genius and distinguished poetic skills. Reiske describes Al-Mutanabbi": "He is a witty person who marries the poet with the philosopher; he is arrogant, selfish, cruel, so pessimistic" (Blachere, p. 448). Hammaer says about him: "Al-Mutanabbi enjoyed a great reputation; the father of poetry whom no one would compete with. His name survived in the East and the West" (Blachere, p. 452). However, all of them agreed that he is the great poet who has embarrassed many critics (Blachere, p. 470-474). Al-Mutanabbi was a poor unknown person who quickly recognized his poetic genius in the Abbasid era; the age of Arabic poetry renaissance. So, his name became well known both in the East and the West.

Behind Al-Mutanabbi's verbal prowess which he exploits to praise the personality of SayfaL-Dawla and to admire his nobility and bravery in the battlefield, lies the boasting character of the poet: "Time is crowded with the narrators of my poetry/ when I write poems, Time starts singing them" (p.13).

Then, the poet's pride develops into extreme arrogance: "I have the heart of a king though my tongue is of a poet" (p. 14). "The features that the poet praises in his competitors are the same features he believes that he possesses; he has the heart of a king and the active talent of a poet who has an imposing personality. The loud voice of the Self blends with the louder tone of the poet" (Sharaf al-Deen, 1982, p.96).

Al-Mutanabbi was extremely bold in expressing his pride. Whenever he praises Sayf al-Dawla, he honors himself, his verbal prowess, courage and skill in battle but most important of all, his poetic creativity. He is distinguished by his bold tongue unlike Shakespeare who is more diplomatic and less direct. Shakespeare leaves it to the reader to understand that his admiration of his poetry is far beyond his admiration of beauty and love. Shakespeare glorifies his poetry more than he boasts of his ego. It is Al-Mutanabbi, not Shakespeare, who says: "Not in my people have I found honor but rather they in me/And my boast is in myself, not in my ancestor" (p. 234)

The paradox suggested in this line is eye-catching. Al-Mutanabbi asserts that his people are honored by him and not the other way around as was the tradition among Arabs in the medieval era. His narcissist nature and proud ego compensates for his feelings of inferiority as much as does his strong wish to become a statesman. Al-Mutanabbi's words to Kafur, the Amir (prince) of Egypt, perfectly embody such a wish:

Unless you bestow me a mansion or a state/ your generosity is hardly enough

Busy with praising you / prevents me from earning my living. (p.237)

It is here when al-Mutanabbi draws the prince's attention to the fact that getting himself busy with writing poetry to praise Kafur, deprives the poet from working for his livelihood. What the prince gives the poet is not enough to enjoy a descent life unless he honors him with a state or a mansion,. Al-Mutanabbi had to wander between the Levant, Iraq, Egypt and Persia seeking personal glory that would replace his unknown ancestry and origins (Al-Hashim, 1959, p. 13). The motivations behind his pride are stronger than those of Shakespeare whose family origins are well- known. However, at the age of twenty-nine, Shakespeare cleverly realizes that artistic patronage is achieved through fame. Both poets needed to praise a significant powerful character to accomplish this glory (Shapiro, 2014, p. 51). Fortunately, both of them have mastered the unique artistic techniques of poetic language which have kept critics busy in all ages. Eventually, both of them have won the fame they were seeking; however, the gains were worth the humiliation of hypocrisy sometimes. Not only has Al-Mutanabbi ranked himself higher than Sayf al-Dawla every now and then, but Shakespeare has also made the immortality of his poetry a must for the glorification of the image of Earl Southampton; his patron.

Al-Mutanabbi's distinguished imagery and figures of speech have gained him the reputation of the greatest Abbasid poet. For example, in this line:

My poem is an angel among all poetry/ as the sun and the world is its sphere,

God is just/ he gave me the word and you the praise. (341)

Al-Mutanabbi asserts the superiority of his poetry over other poems by different poets; it is as superior as an angel to all kinds of creation. The personification suggested by the first line is equally magnificent. If his poetry walks, it would be as beautiful as the sun rotating in the sphere of the whole universe. The two figures of speech suggest how unique his poetry is and it reflects his excessive pride. In another line, 
All my poetry, its verses/ if written, its glamour makes ink white.

Its eloquent words reveal meanings/ stars or your good morals. (p. 343)

The persona compares his verses of poetry to a glamorous light that would deprive ink of its black color. The paradox suggested by whiteness of the light and the black ink creates a colorful visual fantasia. In the second line, he compares his eloquent meanings to shiny stars suggesting that they are well-known, as much as the good morals of Sayf al-Dawla ,and frequently quoted. This brilliant combination of elements of nature, language and morality is wonderful. The third example is even more challenging:

I have written poems/ never settling on one spot

Rhymes that can/ jump over mountains and swim the seas. (p.331)

The persona endows his verses with mythical qualities. They can jump over mountains and swim in the seas. One more example:

Myself and generosity are the same, I am the composer of rhymes/

They, as poison to foes and rage to the envious. (p 338)

As he praises himself, the persona believes that he and generosity were born together and that he is the father of poetry. In an interesting hyperbole, he claims that his poetry has the power of poison killing his enemies and enraging the envious. In addition, Al-Mutanabbi describes how much Sayf al-Dawla appreciates his poetry by comparing it to precious pearls that decorate a woman's neck: "Praising you, my poetry gets more beauty/ as pearls decorating a woman's neck" (p.229).

However, in the following line the metaphor is challenging and difficult enough for the modern reader to realize: "Defeating difficult words by force/ I kill them while others are still chasing" (p. 330). The persona here is proud of his ability to compose eloquent poetry no matter how difficult it is. He compares himself to a hunter capable of catching his prey ,i. e., his meanings and figures of speech while other poets fail. Ironically speaking, the word "kill" does not mean " to end the life of"; it suggests the poet's ability to endow language with life. This playful use of language is so clever and definitely eye catching. In the last example:

Time is crowded with the narrators of my poetry/ when I write poems, Time starts singing them

It motivates the dull to walk/ and inspires listeners to sing

Reward me for my words poets approach you quoting me

Ignore other voices/ only echoes, I am the enchanting bird. (p.227)

Al-Mutanabbi's meaning is closer to Shakespeare who "challenges time and immortalizes the beauty of the noble young man" (Alam al-Deen,2002, p.73). For AL-Mutanabbi, Time is a singer of his poetry which everybody quotes and sings even those who are unable to sing. It has a positive influence over the lazy person who, the moment he hears it, he is willing move actively. In the third line, the persona uses the imperative tone claiming a reward from Sayf al-Dawla whose court is overcrowded with poets repeating al-Mutanabbi's lines. Then he asks the prince to enjoy his poetry because he is the poet who has the genuine voice; the true enchanting bird while the rest of the poets are nothing but an echo of this voice. "Prompted by the envy and jealousy of the rivals when he was at Sayf al-Dawlah's court, alMutanabbi's customary arrogance, his intemperate and unbridled boasting appears in his own poetry" (Abd Razak, p. 2007).

\section{Shakespeare: Pride and Patronage}

On the other hand, William Shakespeare (1564- 1616) was one of the most famous English poets in the Renaissance. Like al-Mutanabbi, he kept researchers and critics extremely busy in the past and in the modern age. Shakespeare's father, prosperous at the time of William's birth, was appointed to several municipal offices and served as an alderman in 1565 , culminating in a term as bailiff in 1568 , the chief magistrate of the town council before falling on hard times for reasons unclear to historians beginning in 1576, when his son William was twelve. His father struggled with serious financial debt which explains why Shakespeare never had a university education (Schoone-Jorgen 2008, 13)

Though he knew a bit of Latin and Greek, " Shakespeare had to work as a teacher for a while before leaving to London. The theatre was clearly prospering and it was frequently attended by nobles who went there riding their horses. Then, Shakespeare worked as a stableman looking after their horses standing in front of the theatre. Soon did he win the trust of those nobles and the care of caretakers of the theatre" (Alam al-Deen,2002, p.71). In addition, Shakespeare worked as a comedian when acting was a mean profession. He expressed his resentment of what he did in the following lines:

Alas! Tis true, I have gone here and there,

And made myself a motely to the view,

Gored mine own thoughts, sold cheap what is most dear. (L. 1-3, Sonnet, 110) 
Within the class system of the Elizabethan England, William Shakespeare did not seem destined for greatness. He was not born into a family of nobility or significant wealth. However, he was lucky to survive in the age of Queen Elizabeth I (1533-1603) who "recognized the importance of the arts to the life and legacy of her nation. She was fond of the theatre, and many of England's greatest playwrights were active during her reign, including Christopher Marlow, Ben Jonson" (Shapiro, 2014, p. 53). Has this golden Age of drama awakened Shakespeare's poetic and dramatic creativity and made him the distinguished poet and playwright who discusses different human values in his literature? Has this age produced his great sonnets in which he celebrates love? Critics praise these sonnets because "as a whole [they] are strikingly intense, conveying a sense of high psychological and moral stakes. They are also remarkably dense, written with a daunting energy, concentration, and compression. Often, the main idea of the poem may be grasped quickly, but the precise movement of thought and feeling, the links among the shifting images, the syntax, tone, and rhetorical structure prove immensely challenging" (Abrams, 2000, p. 1028).

Since Shakespeare's age was the age of nobility and the court, he glorified one of the nobles whom critics differed about his identity. After his first arrival in London, Shakespeare dedicated his two poems "Venus and Adonis" (1593) and "Tarquin and Lucrece" (1594) to his patron. In this narrative poem Shakespeare uses the language of devoted friendship. Some critics believe that it was Henry Wriothesley, the Earl of Southampton who, in 1594, made Shakespeare a member of the Board of Trustees in the palace of Queen Elizabeth. At one time, Lord Southampton gave Shakespeare a thousand pounds to enable him to go through with a purchase which he heard he had mind to (Brown, 1912).Consequently, Shakespeare became a landowner and he wanted to reward this nobleman through his poetry. As he praises his patron, Shakespeare immortalizes him through his poetry. Thus, he glorifies his lines and his talent. It is worth mentioning that Shakespeare discusses the theme of time and immortality seventy-eight times in 126 sonnets (Alam al-Deen, 2002, p. 65). In these sonnets, he glorifies his poetry as well and describes it as immortal.

On the other hand, in Sonnet (18), Shakespeare opens his poem with a rhetorical question suggesting to compare the beauty of the beloved to a beautiful summer's day. The persona praises his beloved's bounty beauty which is warmer, sunnier, more temperate than an English summer day. "But thy eternal summer shall not fade" (L. 6) because it is his poem that will make her beauty eternal. The eternal summer of the youth is preserved forever in the poet's lines. "My love shall in my verse ever live young" (Sonnet, 19, L. 14), alludes to the distinguished power of his words that shall make the beloved everlasting. In other words, immortality is conveyed through being hymned in these "eternal lines".

In Sonnet (23), the persona describes the power of his words. He finds in his poetry- "my books"- a better tongue to speak his heart. His lines are more eloquent than himself; they plead for his love better than he could if he speaks.

$\mathrm{O}$, let my books be then the eloquence

Find dumb presagers of my speaking breast,

Who plead for love and look for recompense

More than that tongue that more hath more expressed. (L. 9-12, Sonnet 23)

The written poem; ironically speaking, speaks loudly his" silent love" so the beloved shall listen through her eyes to his beautiful enchanting words of love.

$\mathrm{O}$, learn to read what silent love hath writ:

To hear with eyes belongs to love's fine wit. (L. 11-12, Sonnet 23)

Nevertheless, in sonnet (35), Shakespeare reveals the dark side of the relationship between the poet and his patron, most likely Earl of Southampton. The persona shares the blame with his lover, who has betrayed him. The fault that the lover has committed is ambiguous; however, it could be a denial of the poet's love. On the other hand, the fair lord is called "the sweet thief which sourly robs from me" (), so it is likely that the offense is the same as that referred to in Sonnets 442: the stealing of the poet's mistress. Despite the pain that his lover has inflicted upon him, the poet decides to assume equal guilt in the corruption of their union. He believes he has authorized his lover's sins: "Authorizing thy trespass with compare" (L. 6). Using an astonishing conceit of the courtroom, he admits that he is an accessory to the crime and a victim pressing charges: "Thy adverse party is thy advocate/ And 'gainst myself a lawful plea commence" (10-11); "the prosecutor of his lover and his lover's chief advocate" (Mabillard, 2009).

The persona here is forgiving his lover his small sins, excusing his transgression by comparing it to other things.

Roses have thorns, and silver mountains mud;

Clouds and eclipses stain both moon and sun,

And loathsome canker lives in sweetbud. (L. 2-4, Sonnet 35)

Everything has its bad side: roses have thorns, sparkling mountains have mud, the sun and the moon are periodically covered up by clouds and eclipses, and disgusting worms live in the sweetest flowers. The poet therefore absolves the young man and defends his betrayal most probably because he loves him, admitting that "All men make faults, and even I in this" (L.5). 
However, the persona reminds Lord Southampton that he is his proponent and defender: "Thy adverse party is thy advocate" (Sonnet 35, L. 10) which brings to the mind the words of blame by Al-Mutanabbi reminding Sayf al-Dawla that he has not rewarded him enough.

You, most just of men to all but me/ you are the source of quarrel and you alone must judge. (332-333)

Nevertheless, such conflicting feelings of blame and forgiveness have created a "civil war" inside the persona: "And 'gainst myself a lawful plea commence/ Such civil war is in my love and hate" (L. 11-12, Sonnet 34). The persona is torn apart by loving and hating his patron who in the previous sonnet sheds tears regretting what he did: "Ah, but those tears are a pearl which thy love sheds/ And they are rich, and ransom all ill deeds" (13-14). The poet pronounces his lord's tears are a rich treasure and a full satisfaction though, cleverly, he tries to deepen feelings of guilt inside his patron. Few lines before, he suggests that tears shed after the offence had been committed could give no adequate relief: "The offender's sorrow lends but weak relief/To him that bears the strong offence's cross" (11-12).

In Sonnet 55, the persona glorifies his poetry that shall outlive marble and gold-plated shrines of princes.

Not marble, nor the gilded monuments

Of princes, shall outlive this powerful rhyme:

But you shall shine more bright in these contents

Than unswept stone, besmeared with sluttish time. (L. 1-4, Sonnet, 55)

At the same time, the poet emphasizes the power of his poetry that shall make his patron shine more bright in these verses than on dust-covered gravestones, ravaged by time. When devastating war shall overturn statues and conflicts destroy the mason's handiwork, nor Mars (the God of war) or fire (effects of war) shall destroy the living record (i. e. the poet's words) of the lord's memory:

When wastful war shall statues overturn

And broils root out the work of masonry

Nor Mars his sword nor war's quick fire shall burn

The living record of your memory (L. 5-7, Sonnet, 55).

Through lines of poetry, Shakespeare's patron defeats "sluttish time", wars and forgetfulness.

This motif of the ravages of time both on love, beauty and life, and how the poet attempts to overcome mortality with his immortal writings reflect to what extent was Shakespeare disturbed by the ceaseless passage of Time. Time is portrayed as a destructive force that only poetry may resist and defeat. It is through his verse that the poet emerges victorious. In an outstanding metaphor, the persona suggests that only the miracle of his verse will allow his love to shine eternally out of the ink of his poem: "Or who his spoil of beauty can forbid?/ $\mathrm{O}$, none, unless this miracle have might,/ That in black ink my love may still shine bright (12-14). The last line brings to the mind Al-Mutanabbi's line: "All my poetry, its verses/ if written, its glamour makes ink white." The paradoxes suggested by "ink", "bright" and "white" and the sweet effect that the visual images create emphasize repeatedly the immortalizing power of poetry.

In Sonnet (71), the persona asks his beloved to forget his poetry:

Nay, if you read this line, remember not

The hand that writ it; for I love you so. (L. 5-6, Sonnet 71)

The contradiction suggested by these two lines is obvious. One cannot read a poem which asks us to forget its writer, without remembering that writer all the time! The ironical wish to forget the writer actually deepens his memory in our thought. This is so much closer to the philosophical conundrum 'Do not read this sentence!'

O, Know, sweet love, I always write of you,

And you and love are still my argument:

So all my best is dressing old words new,

Spending again what is already spent:

For as the sun is daily new and old,

So is my love still telling what is told. (L. 9-14, Sonnet 76)

In this sonnet, the poet justifies why his poetry lacks variation, new ornament and different literary styles. He always writes about his beloved, an old and new theme. Just as the sun is new and old every day, his love tells and retells what he has already said but in different words and figures of speech. What seems to be self-criticism is, indeed, an emphasis on his creative ability to find new words for an old theme. Thus, through his poetry this love shall always shine in a new day as the sun keeps rising after sunset. Again and again, the theme of love is Shakespeare's channel to assert the immortality of his lines. 
The previous examples reveal similar values in the poetry of Shakespeare and al-Mutanabbi. Both glorify the beauty of their poetry while expressing their love to their patrons. Boasting their poetical talent reflect the poet's arrogance and probably hypocrisy towards the addressee. The persona in Shakespeare's sonnets claims that he is glorifying beauty and love. However, between the lines, this glorification is achieved only through the immortal lines of poetry. So, if the names of Sayf aL-Dawla or Lord Southampton are to live forever, it is the poet and only the poet who shall achieve that. Ironically speaking, the addressee who possesses power and status needs the talent of the poor poet. "So long lives this, and this gives life to thee;" "But you shall shine more bright in these contents". Shakespeare definitely suggests that poetry lasts beyond beauty. The poetic ego of the poet survives in the golden age that has fed his arrogance.

\section{Conclusion}

This paper has reached an answer to the question why the two poets resort to hyperbole and boasting. Both poets praise patrons of nobility and distinguished social status. The proud tone suits the subjects who were symbols of greatness in two golden ages when literature witnessed an outstanding prosperity. By living under the magic of their addressees, both poets manage to lay bare their humble social background. As al-Mutanabbi inflames his personal image, Shakespeare boasts the glamour of his poetry which enables him to entertain the blessings of the talented poet. Nonetheless, the literary dialogue between the two poets opens the floor for a strong assumption of clear intertextuality, a theme that requires further research. It is here where the words of Khalil Mutran echo this thought: "On the whole, there is in the writing of Shakespeare a Beduin spirit which is expressed in the continuous return to innate nature" (Mutran, 8, 1976).

\section{References}

Abd Razak, Roshida, R. (2007). Arabic Poet Al-Mutanabbi: A Maslovian Humanistic Approach. Retrieved from http://www.psyartjournal.com

Abrams, M. H. (2000). The Norton Anthology of English Literature. Seventh Edition, Vol. I. New york: Norton and Company.

Alam al-Deen, A. (2002). Shakespear's Sonnets: Selected poems and Critical Insights. Jordan: Dar Ammar.

Al-Barquqi, A. (1980). An Analysis of al-Mutanabbi's Diwan. Beirut: Dar al-Kitab al Arabi.

Al-Hashim, J. (1959). Abu al-Tayyib al-Mutanabbi. Beirut: Dar al-Sharq.

Al-Mutanabbi, A. (1983). Diwan. Beirut: Beirut Publication House.

Askari, S. (2010). "The Psychology of al-Mutanabbi and Sa'di and How it Has Affected their Poetry." Dirasat Fi alLugha al-Arabiya wa Adabuha, 2, 84-103.

Azzab, Sh. (2013). Poetic Cleavage Between the Eastern Bard Abu-Al Tayib Al-Mutanabbi and the Western Bard William Shakespeare. Ph. D. Dissertation. Uiversity of Manouba; Faculty of Letters, Arts and Humanities. Manouba. Retrieved from http://www.academia.edu/4069398/

Blachere, R. (1985). Abu al-Tayyib al-mutanabbi. Trans. Ibrahim al-Kilani. Second Edition. Damascus: Dar al-Fikr.

Brown, H. (1912). Shakespeare's Patrons and Other Essays. London: J. M. Dent 7 Sons.

Driver, M. W. (2009). Shakespeare and the Middle Ages: Essays on the Performance and Adaptation of the Plays with Medieval Sources or Settings. Jefferson: McFarland.

Hasan, A. (1973). AI-Mutanabbi wa Shawqi we Imarati-Shi'r-dirasah wa naqd wa muwazanah. Cairo: Dar al-Ma'arif P.

Al-Haydar, Majed. (2009). The Egyptian Experiment between al-Mutannabi and al-Jawahiri. Retrieved from majidalhydar.blogspot.com/2009/07/blog-post_3644.html

Iseni, A. (2014). Shakespeare and Ibsen: A Comparative Study of Macbeth and Hedda Gabler from 21st Century Radical Feminism Perspective. Journal of Educational and Social Research, 4(4), 30-40.

John, Mohammad Taqi. 2011. "Intertexuality between al-Mutanabbi and International Culture." Lark for Philosophy, Linguistics and Social Sciences, 5 (3), 87-105.

Larkin, Margaret. (1986). Two Examples of Ritha': A Comparison of Al-Mutannabi and Shawqi. Journal of Arabic Literature, 16, 18-39.

Mabillard, A. (2009). Shakespeare Online. 10 Dec. Retrieved from http://www.shakespeareonline.com/sonnets/35detail.html.

Morgan, C. (2009). Literary Similarities between Marlow and Shakespeare. Retrieved from http://themarlowestudies.org/literarysimilarities.html

Mutran, Kh. (1976). Introduction" in Hamlet. Cairo: Dar al-Ma'arif.

Nda, U., \& Margaret, A. (2011). "Sophocles and Shakespeare: A Comparative Study of Classical and Elizabethan Tragedies". Greener Journal of Arts and Humanities, 1(1), 11-20.

Qualey, M. (2013). Someone Crazy Enough To Translate al-Mutanabbi. Retrieved from http://arablit.org/author/mlynxqualey 
Remak, H. H. (1964). Comparative Literature: Its Definition and P. Stallknecht and Horst Function. In Comparative Literature: Method and Perspective. Ed. Newton P. Stallknecht and Horst Frenz. Edwardsville: Southern Illinois UP, P $1-57$.

Schoone-Jorgenm, T. (2008). Shakespeare's Companies: William Shakespeare's Early Career and the Acting Companies, 1577- 1594. Aldershot: Ashgate.

Shakespeare, W. (1994). The Complete Works of William Shakespeare. New York: Barnes \& Nobles.

Shapiro, J. (Ed). (2014). Shakespeare in America: An Anthology from the Revolution to Now. New york: Library of America.

Sharaf al-Deen, Kh. (1982). Al-Mutanabbi: A Nation in One Man. Beirut: Dar al-Hilal.

Shareem, E.Z. (2013). The Image of the Horse in the Poetry of Abu-Tammam and Al-Mutannabi: A Comparative Study. MA Thesis 276 pps. Al-Najah National University, Naples, Palestine.

Vuong, H., \& Mégarbané, P. (2012). Al-Mutanabbî, Le Livre des Sabres, choix de poems. Actes Sud, Sindbad, novembre. 